\title{
Performance of Rice (Oryza sativa L.) Hybrids under Different Nitrogen Levels during Wet Season in New Alluvial Zone of West Bengal
}

\author{
Megha Sana ${ }^{1}$, Rumi Saha ${ }^{1}$, Subhajit Pal $^{2}$, Sukanta Pal ${ }^{1}$ and Krishnendu Mondal ${ }^{1}$ \\ ${ }^{1}$ Department of Agronomy, Faculty of Agriculture, Bidhan Chandra Krishi Viswavidyalaya, \\ Mohanpur- 741252, Nadia, West Bengal, India \\ ${ }^{2}$ Department of soil Science and Agricultural Chemistry, Faculty of Agriculture, Dr. Rajendra \\ Prasad Central Agricultural University, Pusa (Samastipur), Bihar- 848125 \\ *Corresponding author
}

\begin{tabular}{l} 
K ey w o r d s \\
$\begin{array}{l}\text { Oryza sativa, } \\
\text { Nitrogen levels, } \\
\text { kharif seasons, } \\
\mathrm{N}_{4} \text { level }\end{array}$ \\
Article Info \\
$\begin{array}{l}\text { Accepted: } \\
\text { 20 June } 2020 \\
\text { Available Online: } \\
\text { 10 July } 2020\end{array}$ \\
\hline
\end{tabular}

\section{A B S T R A C T}

Effect of rice hybrids to nitrogen levels was studied during kharif seasons of 2018 and 2019 at Regional-Research Sub-Station (RRSS) Chakdaha of BCKV under new alluvial zone of West Bengal. The experiment was laid out in Factorial Randomized Block Design (FRBD) with 10 treatment combinations having with two hybrid rice varieties viz., $\mathrm{V}_{1}$ (PAN 2112 Gold), $\mathrm{V}_{2}(\mathrm{KRH}-2)$ and five nitrogen levels viz. $\mathrm{N}_{1}\left(0: 60: 60 \mathrm{~N}: \mathrm{P}_{2} \mathrm{O}_{5}: \mathrm{K}_{2} \mathrm{O}\right.$ $\mathrm{Kg} / \mathrm{ha}), \mathrm{N}_{2}\left(50: 60: 60 \mathrm{~N}: \mathrm{P}_{2} \mathrm{O}_{5}: \mathrm{K}_{2} \mathrm{O} \mathrm{Kg} / \mathrm{ha}\right), \mathrm{N}_{3}\left(100: 50: 50 \mathrm{~N}: \mathrm{P}_{2} \mathrm{O}_{5}: \mathrm{K}_{2} \mathrm{O}\right.$ $\mathrm{Kg} / \mathrm{ha}), \mathrm{N}_{4}\left(150: 60: 60 \mathrm{~N}: \mathrm{P}_{2} \mathrm{O}_{5}: \mathrm{K}_{2} \mathrm{O} \mathrm{Kg} / \mathrm{ha}\right), \mathrm{N}_{5}\left(200: 60: 60 \mathrm{~N}: \mathrm{P}_{2} \mathrm{O}_{5}: \mathrm{K}_{2} \mathrm{O}\right.$ $\mathrm{Kg} / \mathrm{ha}$ with four replicates. Experimental results revealed that almost all the growth parameters gave significantly superior performance in the variety PAN 2112 Gold and $\mathrm{N}_{4}$ level of fertilization. The maximum grain yield $(5.10 \mathrm{t} / \mathrm{ha})$ was recorded in the variety $\mathrm{V}_{1}$ in combination with $\mathrm{N} 4$ level of nitrogen which were $6.69 \%$ more than KRH-2. Highest harvest index $(50.86 \%)$ was noticed in same treatment combination.

\section{Introduction}

Rice (Oryza sativa L.) is an important cereal crop and grown across the world. It is an important cereal crop next to wheat which accounts for the major dietary energy requirement of Asian rural people as more than $90 \%$ of rice is grown and consumed in Asia. It is a principal source of food for more than half of the world's population and also predicted that a $50-60 \%$ increase in rice production will be required to meet demand from population growth by 2025 . To sustain the self sufficiency in coming decades, the production of rice needs to be increased every year by almost 2 million tonnes. The challenging task of plateauing trend observed in yield potential of high yielding rice varieties and decreasing natural resource base can be done by hybrid rice technology. This 
increase in production should be achieved without disturbing the delicate environmental base. Many genetic approaches being explored to break the yield barrier in rice, hybrid rice technology appears to be the most feasible and readily adaptable one. Rice hybrid produces about $14-28 \%$ higher grain yield than inbred cultivars (Siddiq, 2006). In west Bengal the yield potential of hybrid rice is 4-6 t/ha during kharif season. Earlier it was mainly concentrated in North Bengal districts like Coochbehar, Jalpaiguri, Malda, North and South Dinajpur but now it is cultivated in South Bengal districts like Purulia, Bankura, South 24 Pgs, Nadia etc.

Nutrient requirement of hybrid rice is generally more than the high yielding varieties. It is recommended after the evaluating of soil nutrient status. Inorganic fertilizers especially nitrogen plays an important role towards cultivation of hybrid rice. Inadequate nitrogen in soil results in reduced leaf area, limiting light interception thereby causing reduced photosynthesis which finally give poor biomass growth and grain yield (Sinclair, 1990). As nitrogen fertilizer is important for the grain yield of the rice plant it is necessary to know what the best dose is for each variety as well as its influence on components of yield. Different variety shows different yield potential of hybrid rice at different nitrogen doses. Therefore, present investigation was carried out with a view to develop a package involving optimization of nitrogen doses and variety for the overall improvement of productivity of hybrid rice.

\section{Materials and Methods}

A field experiment was conducted in 2018 and 2019 during two consecutive wet seasons of at Regional Research Sub-Station, Chakdaha under Bidhan Chandar Krishi Viswavidyalaya West Bengal. The climate of the experimental site is humid subtropical with hot humid, long summer and mild short winter. The experiment was conducted under irrigated shallow medium land situation, having medium fertility status with good drainage facility. The soil of the experimental field was sandy clay loam in texture (Entisol) with $\mathrm{pH} 7.0$, EC $0.61 \mathrm{ds} \mathrm{m}^{-1}$, organic carbon $0.38 \%$, available $\mathrm{N} 184 \mathrm{~kg} \mathrm{ha}^{-1}$, available $\mathrm{P}$ $16.00 \mathrm{~kg} \mathrm{ha}^{-1}$ and available K $126.10 \mathrm{~kg} \mathrm{ha}^{-1}$. The experiment was laid out in Factorial Randomized Block Design (FRBD) with 3 (three) replicates. The $4 \mathrm{~m} \times 3 \mathrm{~m}$ experimental plots were made with $0.5 \mathrm{~m}$ bunds leaving $1 \mathrm{~m}$ irrigation channel in between. Hybrid rice varieties used in the experiment were PAN 2112 Gold and KRH-2. Five levels of nitrogen [Control, $50 \mathrm{~kg} / \mathrm{ha}$ nitrogen, $100 \mathrm{~kg} / \mathrm{ha}$ nitrogen, $150 \mathrm{~kg} / \mathrm{ha}$ nitrogen and $200 \mathrm{~kg} / \mathrm{ha}$ nitrogen] were applied to prescheduled experimental plots. $60 \mathrm{~kg} / \mathrm{ha}$ $\mathrm{P}_{2} \mathrm{O}_{5}$ and $60 \mathrm{~kg} / \mathrm{ha} \mathrm{K}_{2} \mathrm{O}$ are common in all the above treatments. One fourth of total $\mathrm{N}$, entire amount of $\mathrm{P}$ and three fourths of $\mathrm{K}$ were applied as basal after draining out the standing water but before final puddling. Remaining $\mathrm{N}$ was top dressed in three equal splits, each at three weeks after transplanting, panicle initiation and panicle emergence stages. Remaining one fourth of $\mathrm{K}$ was also applied at panicle initiation stage. Well germinated seeds of hybrid rice (var. PAN 2112 Gold and KRH-2) @ $15 \mathrm{~g} / \mathrm{m}^{2}$ were and 23 days old seedlings were transplanted. The seedlings were uprooted and transplanted at the spacing of $20 \mathrm{~cm} \times 15 \mathrm{~cm}$. Single seedling were planted hill ${ }^{-1}$ at a depth of 2-3 cm as per all treatments. Nitrogen, phosphorus and potash in the form of urea, single super phosphate and muriate of potash were applied as per treatment. Gap filling was done seven days after transplanting to keep same plant population density for every plot. All other cultural and plant-protection measures were also adopted as recommended for the region (Banerjee and Pal, 2009). The crop was 
harvested when the plant become yellowish to brown and had around 14\% grain moisture level. Data on different yield components were recorded at harvest. Plot-wise crops were harvested threshed. Grain and straw were then properly sun-dried, weighed and finally converted into t/ha. Plant samples from each treatment were collected, oven-dried, and ground for analyzing total recoveries of $\mathrm{N}, \mathrm{P}$ and $\mathrm{K}$ at harvesting following standard procedures.

\section{Results and Discussion}

\section{Growth parameters of rice}

There was a significant influence of all growth parameters like plant height, number of tillers $/ \mathrm{m}^{2}$, LAI, DMA, chlorophyll content and CGR. PAN 2112 Gold showed the highest result over KRH-2. PAN 2112 Gold showed more chlorophyll content than KRH-2 might be due to the varietal characters. Influence of nitrogen level was also significant in case of all growth parameters namely plant height, number of tillers $/ \mathrm{m}^{2}$, LAI, DMA, chlorophyll content and CGR (Table 1) and application of $150 \mathrm{~kg} \mathrm{~N} / \mathrm{ha}$ showed the best result accounting 12.9, 35.8, $31.8,52.5,10.4$ and $41.05 \%$ increase over control respectively. Similar findings were also reported by Mishra et al., (2003), more nitrogen availability encourage carbohydrate synthesis. Except number of tillers $/ \mathrm{m}^{2}$ and chlorophyll content all growth parameters showed significant result in case of combination approach. All the measured yield attributes were higher under the PAN 2112 Gold in combination with $150 \mathrm{~kg} \mathrm{~N} / \mathrm{ha}$ level. Similar observations were also reported by Pandey et al., (2007), Bera and Pramanik (2013) and Singh et al., (2009).

\section{Yield and harvest index}

The grain yield, straw yield and harvest index of paddy hybrid significantly varied among the varieties and different levels of nitrogen. The grain yield of variety PAN 2112 Gold $(5.10 \mathrm{t} / \mathrm{ha})$ was $6.69 \%$ higher than KRH-2. The difference in their yield was due to their variation in yield component. Highest straw yield and harvest Index was 6.10 t/ha and $44.96 \%$ respectively in case of PAN 2112 Gold variety (Table 2). Regarding nitrogen levels highest grain yield (6.27 t/ha) showed with the application of $\mathrm{N}_{4}$ (i.e.150:60:60 N: $\mathrm{P}_{2} \mathrm{O}_{5}: \mathrm{K}_{2} \mathrm{O} \mathrm{Kg} / \mathrm{ha}$ ) nutrient level which was $85.50 \%$ more than the control treatment. But the highest straw yield was recorded from $\mathrm{N}_{5}$ level of nitrogen dose i.e. $200 \mathrm{~kg} / \mathrm{ha}$. There was progressive and significant increase in straw yield with each incremental dose of nitrogen applied during the course of investigation. It is also observed that increasing trend of nitrogen level increased yield (Jaswal et al., 2001). Except the grain yield the interaction between varieties and nitrogen levels was statistically significant in case of straw yield and harvest Index. PAN 2112 Gold in combination with $100 \mathrm{~kg} \mathrm{~N} / \mathrm{ha}$ gave the highest straw yield.

\section{Nutrient uptake}

Total nutrient uptake by grain and straw varied significantly with the varieties, nitrogen levels and interaction effect between variety and nitrogen in case of total nitrogen and phosphorus but total potassium uptake by grain and straw did not show any significant relationship among varieties. In nitrogen levels and interaction effect there were significant difference in values in case of total potassium uptake. V1 showed higher value $(96.57 \mathrm{~kg} / \mathrm{ha})$ than KRH-2 (91.90 kg/ha) towards $\mathrm{N}$ uptake but $\mathrm{KRH}-2$ had significant superior value $(30.78 \mathrm{~kg} / \mathrm{ha})$ than PAN 2112 Gold (30.26 kg/ha) for total P uptake (Table 3). Among five nitrogen levels N4 i.e. $150 \mathrm{~kg}$ $\mathrm{N} /$ ha recorded maximum value in case of total $\mathrm{N}, \mathrm{P}, \mathrm{K}$ uptake. 
Table.1 Effect of nitrogen levels and varieties on growth parameters of hybrid rice during wet season (Pooled value of 2 years)

\begin{tabular}{|c|c|c|c|c|c|c|c|c|c|}
\hline \multirow{3}{*}{$\begin{array}{c}\text { Nitrogen } \\
\text { management }\end{array}$} & \multicolumn{3}{|c|}{ Plant height at 75 DAS } & \multicolumn{3}{|c|}{ No. of tillers $/ \mathrm{m}^{2}$ at $75 \mathrm{DAS}$} & \multicolumn{3}{|c|}{ LAI at 75 DAS } \\
\hline & \multicolumn{9}{|c|}{ Variety } \\
\hline & V1 & V2 & Mean & V1 & V2 & Mean & V1 & V2 & Mean \\
\hline N1 & 100.49 & 99.13 & 99.81 & 369.93 & 344.85 & 357.39 & 2.85 & 2.80 & 2.83 \\
\hline N2 & 103.82 & 104.89 & 104.36 & 419.15 & 376.20 & 397.67 & 2.95 & 2.85 & 2.90 \\
\hline N3 & 105.11 & 107.96 & 106.54 & 438.90 & 410.69 & 424.79 & 3.60 & 3.50 & 3.55 \\
\hline N4 & 112.95 & 112.40 & 112.68 & 493.67 & 477.30 & 485.48 & 3.75 & 3.70 & 3.73 \\
\hline \multirow[t]{2}{*}{ N5 } & 108.31 & 110.48 & 109.40 & 466.17 & 448.31 & 457.24 & 3.85 & 3.80 & 3.83 \\
\hline & Sem \pm & CD 5\% & & Sem \pm & $\begin{array}{l}\text { CD } \\
\mathbf{5 \%}\end{array}$ & & $\operatorname{Sem} \pm$ & CD 5\% & \\
\hline $\mathbf{N}$ & 0.038 & 0.112 & & 3.743 & 10.920 & & 0.004 & 0.013 & \\
\hline $\mathbf{V}$ & 0.024 & 0.071 & & 2.367 & 6.906 & & 0.003 & 0.008 & \\
\hline $\mathbf{N x V}$ & 0.054 & 0.158 & & 5.294 & NS & & 0.006 & 0.018 & \\
\hline
\end{tabular}

\begin{tabular}{|c|c|c|c|c|c|c|c|c|c|}
\hline \multirow[t]{3}{*}{$\begin{array}{c}\text { Nitrogen } \\
\text { management }\end{array}$} & \multicolumn{3}{|c|}{ DMA at 75 DAT } & \multicolumn{3}{|c|}{$\begin{array}{c}\text { Chlorophyll content } 75 \\
\text { DAT }\end{array}$} & \multicolumn{3}{|c|}{ CGR at 25-50 DAT } \\
\hline & \multicolumn{9}{|c|}{ Variety } \\
\hline & V1 & V2 & Mean & V1 & $\mathbf{V} 2$ & Mean & V1 & $\mathbf{V} 2$ & Mean \\
\hline N1 & 720.95 & 702.27 & 711.61 & 1.92 & 1.93 & 1.93 & 19.07 & 19.51 & 19.29 \\
\hline N2 & 761.01 & 895.73 & 828.37 & 1.97 & 1.73 & 1.85 & 19.89 & 25.58 & 22.74 \\
\hline N3 & 890.49 & 895.73 & 893.11 & 1.81 & 1.83 & 1.82 & 21.45 & 23.65 & 22.55 \\
\hline N4 & 1092.5 & 1078.6 & 1085.5 & 2.16 & 2.10 & 2.13 & 26.44 & 27.98 & 27.21 \\
\hline \multirow[t]{2}{*}{ N5 } & 898.89 & 1075.2 & 987.07 & 2.39 & 2.20 & 2.30 & 21.16 & 28.22 & 24.69 \\
\hline & Sem \pm & CD $5 \%$ & & $\operatorname{Sem} \pm$ & CD $5 \%$ & & $\operatorname{Sem} \pm$ & CD $5 \%$ & \\
\hline $\mathbf{N}$ & 73.29 & 217.67 & & 0.023 & 0.068 & & 1.81 & 5.382 & \\
\hline $\mathbf{V}$ & 48.14 & 137.67 & & 0.015 & 0.043 & & 1.19 & 3.404 & \\
\hline $\mathbf{N x V}$ & 105.78 & 307.83 & & 0.033 & NS & & 2.62 & 7.612 & \\
\hline
\end{tabular}

V1= PAN 2112 Gold, V2= KRH-2, N1=Control, N2=50:60:60 kg/ha, N3=100:60:60 kg/ha, N4=150:60:60 Kg/ha, N5=200:60:60 kg/ha 
Table.2 Effect of nitrogen levels and varieties on yields (t/ha) and harvest index (\%) of hybrid rice (Pooled value of 2 years)

\begin{tabular}{|c|c|c|c|c|c|c|c|c|c|}
\hline \multirow{3}{*}{$\begin{array}{c}\text { Nitrogen } \\
\text { management }\end{array}$} & \multicolumn{3}{|c|}{ Grain yield (t/ha) } & \multicolumn{3}{|c|}{ Straw yield (t/ha) } & \multicolumn{3}{|c|}{ Harvest index (\%) } \\
\hline & \multicolumn{9}{|c|}{ Variety } \\
\hline & V1 & $\mathbf{V 2}$ & Mean & V1 & $\mathbf{V 2}$ & Mean & V1 & $\mathbf{V 2}$ & Mean \\
\hline N1 & 3.46 & 3.30 & 3.38 & 5.47 & 5.34 & 5.41 & 38.76 & 38.20 & 38.48 \\
\hline N2 & 4.06 & 3.99 & 4.03 & 5.84 & 5.46 & 5.65 & 41.02 & 42.23 & 41.63 \\
\hline N3 & 5.59 & 4.86 & 5.23 & 6.6 & 6.02 & 6.31 & 45.86 & 44.66 & 45.26 \\
\hline N4 & 6.58 & 5.95 & 6.27 & 6.36 & 6.2 & 6.28 & 50.86 & 48.98 & 49.92 \\
\hline \multirow[t]{2}{*}{ N5 } & 5.83 & 5.79 & 5.81 & 6.24 & 6.48 & 6.36 & 48.32 & 47.20 & 47.76 \\
\hline & Sem \pm & CD $5 \%$ & & Sem \pm & $\begin{array}{l}\text { CD } \\
5 \%\end{array}$ & & Sem \pm & CD 5\% & \\
\hline $\mathbf{N}$ & 0.146 & 0.425 & & 0.012 & 0.036 & & 0.077 & 0.224 & \\
\hline $\mathbf{V}$ & 0.092 & 0.269 & & 0.008 & 0.023 & & 0.121 & 0.354 & \\
\hline $\mathbf{N x V}$ & 0.206 & NS & & 0.018 & 0.051 & & 0.172 & 0.501 & \\
\hline
\end{tabular}

V1= PAN 2112 Gold, V2= KRH-2, N1=Control, N2=50:60:60 kg/ha, N3=100:60:60 kg/ha, N4=150:60:60 Kg/ha, N5=200:60:60 kg/ha

Table.3 Effect of nitrogen levels and varieties on $\mathrm{N}$ uptake $(\mathrm{kg} / \mathrm{ha}), \mathrm{P}$ uptake $(\mathrm{kg} / \mathrm{ha})$ and $\mathrm{K}$ uptake $(\mathrm{kg} / \mathrm{ha})$ of grain + straw after harvest of hybrid rice (Pooled value of 2 years)

\begin{tabular}{|c|c|c|c|c|c|c|c|c|c|}
\hline \multirow{3}{*}{$\begin{array}{c}\text { Nitrogen } \\
\text { management }\end{array}$} & \multicolumn{3}{|c|}{$\mathbf{N}$ uptake } & \multicolumn{3}{|c|}{ P uptake } & \multicolumn{3}{|c|}{ K uptake } \\
\hline & \multicolumn{9}{|c|}{ Variety } \\
\hline & V1 & V2 & Mean & V1 & V2 & Mean & V1 & V2 & Mean \\
\hline N1 & 62.32 & 59.07 & 60.70 & 24.50 & 24.60 & 24.55 & 84.60 & 89.04 & 86.82 \\
\hline N2 & 73.69 & 77.72 & 75.21 & 27.05 & 26.61 & 26.83 & $\begin{array}{c}102.8 \\
4\end{array}$ & 100.20 & $\begin{array}{c}101.5 \\
2\end{array}$ \\
\hline N3 & 88.61 & 95.95 & 92.28 & 29.50 & 27.84 & 28.67 & $\begin{array}{c}107.2 \\
6\end{array}$ & 104.25 & $\begin{array}{c}105.7 \\
5\end{array}$ \\
\hline N4 & $\begin{array}{c}140.4 \\
0\end{array}$ & 134.15 & $\begin{array}{c}137.2 \\
8\end{array}$ & 40.56 & 39.02 & 39.79 & $\begin{array}{c}124.9 \\
7\end{array}$ & 123.90 & $\begin{array}{c}124.4 \\
4\end{array}$ \\
\hline N5 & $\begin{array}{c}109.7 \\
0\end{array}$ & 100.71 & $\begin{array}{c}105.2 \\
1\end{array}$ & 31.70 & 33.82 & 32.76 & $\begin{array}{c}118.0 \\
2\end{array}$ & 118.31 & $\begin{array}{c}118.1 \\
6\end{array}$ \\
\hline & Sem \pm & CD 5\% & & Sem \pm & $\begin{array}{l}\text { CD } \\
\mathbf{5 \%}\end{array}$ & & $\operatorname{Sem} \pm$ & CD 5\% & \\
\hline $\mathbf{N}$ & 0.426 & 1.242 & & 0.087 & 0.253 & & 0.148 & 0.432 & \\
\hline V & 0.269 & 0.785 & & 0.055 & 0.160 & & 0.094 & NS & \\
\hline $\mathrm{NxV}$ & 0.602 & 1.756 & & 0.123 & 0.358 & & 0.209 & 0.610 & \\
\hline
\end{tabular}

V1= PAN 2112 Gold, V2= KRH-2, N1=Control, N2=50:60:60 kg/ha, N3=100:60:60 kg/ha, N4=150:60:60 Kg/ha, $\mathrm{N} 5=200: 60: 60 \mathrm{~kg} / \mathrm{ha}$ 
The maximum values of $\mathrm{N}, \mathrm{P}, \mathrm{K}$ uptake were $137.28 \mathrm{~kg} / \mathrm{ha}, 39.79 \mathrm{~kg} / \mathrm{ha}, 124.44 \mathrm{~kg} / \mathrm{ha}$ respectively. The least values were observed in control plot where no nitrogen was applied and the percent increase over control to the $\mathrm{N} 4$ treatment in case of $\mathrm{N}, \mathrm{P}, \mathrm{K}$ uptake were 126.16, 62.07, 43.31 respectively. Regarding interaction effect between variety and nitrogen levels PAN 2112 Gold recorded significantly highest value in combination with $150 \mathrm{~kg} \mathrm{~N} /$ ha towards total NPK uptake by grain and straw. KRH- 2 variety also showed highest value in combination with N4 level of fertilization.

The investigation concludes with the finding PAN 2112 Gold can be recommended for South Bengal locations contributing a yield of $5.10 \mathrm{t} / \mathrm{ha}$ as an Aman crop. Hybrid rice responds up to $150 \mathrm{~kg} / \mathrm{ha}$ of Nitrogen application. These two factors in combination can be recommended to the farmers.

\section{References}

Banerjee, H. And Pal, S. 2009. Integrated nutrient management for rice rice cropping system. Oryza. 46 (2-36).

Bera,-A-K; Pramanik,-K (2013). Response of rice hybrids to nitrogen levels under lateritic zone of West Bengal, India. International-Journal-of-Bio-resourceand- Stress-Management.; 4(2): 161165.

Jaiswal, V. P. and Singh G. R. 2001. Effect of planting methods and levels of nitrogen on the growth and yield of rice and on succeeding wheat. Indian Journal of Agronomy. 46(1): 5-11.

Mishra, B., Viraktamath, B.C., ahmed, M.I., Ramesha, M.S., Vijayakumar, C.H.M May,-2002. (2003) Hybrid rice development and use in India Hybridrice-for- food-security,-povertyalleviation-and-environmental-

protection-Proceedings- of-the- $4^{\text {th }}$ International-Symposium-on-HybridRice,Hanoi, Vietnam,14-170265- 268.

Pandey N, Verma AK, and Tripathi RS. (2007). Evalution of different nutrient management practices on the performance of rice hybrid during dry season. Oryza. 44 (4) : 311- 314.

Siddiq, E.A. 2006. Rice production strategy for the 21st century, Oryza, 30: 186196.

Sinclair, T.N. 1990. Nitrogen influence on the physiology of crop yield. In: Theoretical Production Ecology: Reflections and Prospects (Eds.: R. Rabbinge, J. Goudriaan, H. van Keulen, F.W.T.P. de Vries, H.H. van Laar). Pudoc Wageningen, p.41-55.

Singh, A.K., Chandra, U. And Singh, T. (2009). Effect of different fertilizer levels on chlorophyll content, growth and yield of hybrid rice. Annals-ofPlant- Physiology 23(1): 77-79.

\section{How to cite this article:}

Megha Sana, Rumi Saha, Subhajit Pal, Sukanta Pal and Krishnendu Mondal. 2020. Performance of Rice (Oryza sativa L.) Hybrids under Different Nitrogen Levels during Wet Season in New Alluvial Zone of West Bengal. Int.J.Curr.Microbiol.App.Sci. 9(07): 2352-2357. doi: https://doi.org/10.20546/ijcmas.2020.907.274 